\title{
Crossing Cultural Boundaries
}

HOWARD MCNAUGHTON

UNIVERSITY OF CANTERBURY, NZ

Handel Kashope Wright and Meaghan Morris (eds)

Cultural Studies of Transnationalism

Routledge, Abingdon, 2012

ISBN 139780415685825

RRP $£ 28.00$

The essays in this collection derive from a 2006 conference in Istanbul, part of a series known inside cultural studies as 'Crossroads'. Neither the editors nor, it seems, the conference organisers define 'transnationalism', presumably to avoid a programmatic approach. There is good precedent for this: Peter Sellars, director of the 1990 and 1993 Los Angeles festivals, deliberately did not offer audience aids such as printed explanatory material, leaving theatre-goers to make their own sense out of work which often crossed complex language and cultural boundaries:

'People ... had to look at stuff they did not know how to react to. That

began to be an authentic experience. They simply had to react as human

beings. They did not know [how to react]. They simply had to look.'1

For Sellars this may be laudably Brechtian but at Istanbul there was no such objective; some contributors find unexpected angles and perspectives on 'transnationalism', while others settle for 'close enough' terms such as hybridity. 
The collection proper begins with Raka Shome's 'Post-colonial Reflections on the "Internationalization of Cultural Studies"'. This is an important chapter in a volume such as this, and sketches in broad terms the scope of the subject. It is, in general, abstract in its approach, which makes it not particularly reader friendly, and it is with some relief that one finds her quoting Dipesh Chakrabarty, a master at substantiating finely theorised arguments through strategic use of examples. But Shome's own analysis is not entirely without such illustration, as when she emphasises the effect of the general requirement that papers be written in English: the hegemony of the English language emerges as a major constraint on internationalisation.

Similarly broad-spectrum is Allaine Cerwonka's 'Higher Education "Reform", Hegemony, and Neo-Cold War Ideology: Lessons from Eastern Europe'. This, too, is an important contribution and a field of analysis that is fascinating the closer one gets to it but such a huge topic really deserves more development than a conference paper can allow.

Kumu Kahua Theatre, in downtown Honolulu on O'ahu, initially seems a promising test case but the writer, Ming-Bao Yue, a Stanford-educated graduate now at Manoa, smuggles the word 'hybridity' into her title and this in fact steers the direction of the whole chapter. Working through a close analysis of one particular play, Yue offers an astute scrutiny of inter-racial tensions and tolerances that, however, is difficult to square up precisely with any one definition of 'transnationalism'. As the only theatre in Hawai'i dealing exclusively with local plays, Kumu Kahua would seem an ideal case for 'transnational' analysis, especially as the writer is a specialist in diasporic studies. Kumu Kahua is just down the road from Pearl Harbor, the attack on which heightened inter-racial tensions on an extreme scale. In the play, however, these seem to dissolve within a generation as the machinations of 'hybridity' kick in. Well outside the tourist circuit, Kumu Kahua is a very interesting enterprise and certainly worth a visit but as qualitative research through a single play, one wonders what force these generalisations may command.

By contrast, Shouleh Vatanabadi's 'Translating the Transnational: Teaching the "Other" in Translation' raises the important question of why some books get translated while others don't. Vatanabadi, a graduate of the State University of New York at Binghamton, effectively uses an interrogative style to problematise the issue, 
a type of rhetoric one associates with Spivak. Certainly, such an approach generates more questions than it can answer but that is totally preferable to trite reductivism. Vatanabadi finds a key text in Azar Nafisi's Reading Lolita in Tehran, which she describes as a 'highly problematic' text of autoethnography. ${ }^{2}$ Extensively prescribed in Arab Studies courses, this text is a powerful force in shaping Western assumptions about Middle Eastern women. As Vatanabadi points out, Nafisi accentuates this discursive strategy by channelling her narrative through the figure of an Iranian professor of English returning to her homeland after major shifts in its political equilibrium, at the same time representing the West as a world of freedom and tolerance. The representational dynamic is thus similar to Said's concept of the 'return' of Orientalism: the West is allowed to define itself by its own rhetoric, as well as indulging its own privileged stereotypes about Middle Eastern women as victims of tradition, patriarchy, religion and poverty. This is an important point that deserves close scrutiny but the chapter seems to lose direction and in its last few pages it drifts through unrelated generalisations rather than analysing precisely what makes Nafisi's book 'highly problematic'.

Boulou Ebanda de B'béri's 'Transgeographical Practices of Marronage in some African Films: Peck, Sissako and Téno, the New Griots of New Times' winds up the collection. This chapter pays relatively brief attention to the three 'African' films alluded to in the title although there are very interesting insights that emerge through the discussion of Raoul Peck's masterful Lumumba (2000). Peck is a Haitian filmmaker, while de B'béri is on the staff at the University of Ottawa, where he is the founding director of the Audiovisual Media Lab for the Study of Cultures and Societies. The chapter is wide-ranging and intermittently uses psychoanalysis so it is perhaps unsurprising that de B'béri frequently cites Homi Bhabha. One suspects, however, a strong influence from Henry Louis Gates, whose 1988 Signifying Monkey could be seen as the grounding of the semiotic dimension in the analysis. In Lumumba, however, Peck mobilises something like the multi-tongued narrative of the griot to tactically counter the authority of the colonising force. This relates to the concept of 'marronage' introduced in the title, which de B'béri relates to 'counterseduction', arguing that marronage (a term generally applied to the strategies and survival arts involved in escaping and resisting plantation slavery) incorporates both the signifier of the slave's resistance and 'the seduction of colonial power'. He 
also points out that most maroons were noble slaves, masters of dispersion and simulacra, so that their work may be seen as a hijack of the resources of the coloniser. This argument thus comes very close to Homi Bhabha's early principle of mimicry, though the precise parallel de B'béri suggests is with the 'agonistic enunciative' practices of the Harlem Renaissance. ${ }^{3}$

Along similar lines is Sonja Stanley-Niaah's comparison of Jamaican dancehall and South African Kwaito. On staff at the University of the West Indies, StanleyNiaah is well placed to chart the various music and performance elements loosely associated with dancehall. Jamaica produced the first dub poetry in today's sense and beside this Stanley-Niaah places Kwaito, a performance form commonly seen as grounded in Soweto and tentatively associated by some with reggae. For its detailed account of ghetto culture, this chapter is excellent and appears to be informed by an intimate knowledge of the two main contexts. However, when a gesture is made towards factoring in transnationalism, it is clearly less successful. Using the word 'export' unproblematically, Stanley-Niaah apparently overlooks the way Dick Hebdige and numerous others have emphasised the central importance of factoring in geographical and historical specificity when accounting for the movement of cultural products from one urban environment to another. Studies of punk in particular have shown that when a specific cultural formation spreads internationally the instability of its meaning generates new patterns of significance. Indeed, anyone who looks at the DVD LKJ Live in Paris cannot fail to note the huge difference between the urbane Paris audience and the Jamaican students who invented the form. That important limitation aside, this is a carefully observed analysis, and the parallels Stanley-Niaah finds between the two performance cultures are highly suggestive. Going beyond this, Sujeong Kim's 'Social Discourses on a Korean Drama' is basically audience ethnography. It tracks the reception of a Korean television series in other parts of East Asia. While as ethnography it is not exactly profound, it does acknowledge the main demographic principle that governs reception (audience) and hence increases critical understanding of the transnational cultural phenomenon known as the 'Korean wave'.

It is worth noting that this is actually the third life of this collection. It first appeared as a collection of conference papers, then as a special double issue of Cultural Studies, and now as a simultaneous publication in paperback and hardback. 
In view of that, the present Routledge version shows an alarming number of instances of bad proofing. The word 'autoethnography' is spelled in three different ways on a single page, but perhaps worse is the frequency of its usage: if such a clunky word cannot be avoided, its repetition still can. Also, many fieldworkersincluding Eric Michaels-have cast doubt as to whether 'autoethnography' can exist in any pure form. In these tight fiscal times, a determinant on whether to buy this volume will commonly be whether libraries already have it in another form (remembering that Cultural Studies is also available electronically). However, 'transnationalism' is a major growth area in cultural studies scholarship and a significant number of these contributions certainly claim space in the contemporary research library.

Howard McNaughton is Professor of English and Cultural Studies at the University of Canterbury, New Zealand. His most recent publications have been on cultural change in China, particularly since the 'opening up' and the Beijing Olympics.

\footnotetext{
-NOTES

1 Peter Sellars, quoted in Barbara Kirshenblatt-Gimblett, Destination Culture: Tourism, Museums, Heritage, University of California Press, Berkeley, 1998, p. 203.

2 Azar Nafisi, Reading Lolita in Tehran: A Memoir in Books, I.B. Taurus, London, 2003.

${ }^{3}$ Homi K. Bhabha, The Location of Culture, Routledge, London, 1994, p. 207.
} 